\title{
PRAETORIUS VERSUS ZARLINO THE QUESTION OF MODES
}

\author{
NEJC SUKLJAN \\ Univerza v Ljubljani, Filozofska fakulteta
}

Izvleček: Prispevek obravnava vprašanje modusov, kot se kaže v spisih Istitutioni harmoniche Gioseffa Zarlina in Syntagma musicum Michaela Praetoriusa. Predstavitvi sistema dvanajstih modusov, ki ga je Zarlino prevzel od Heinricha Glareana, in sprememb, ki jih je vanj vpeljal, sledi njegova primerjava s preglednim prikazom modusov, kot ga je v svojem spisu predstavil Praetorius.

Ključne besede: Gioseffo Zarlino, Michael Praetorius, glasbena teorija, modusi
Abstract: This article deals with the question of modes as it is discussed in Gioseffo Zarlino's Istitutioni harmoniche and Michael Praetorius's Syntagma musicum. First, Gioseffo Zarlino's adoption of Heinrich Glarean's system of twelve modes is presented, along with the changes he introduced. Gioseffo Zarlino's system is then compared to that of Michael Praetorius.

Keywords: Gioseffo Zarlino, Michael Praetorius, music theory, modes

In 1558 Gioseffo Zarlino (c. 1517-1590) published the first edition of his monumental treatise on music, Le istitutioni harmoniche. Already during Zarlino's lifetime the book became widely known: Zarlino's theoretical concepts were discussed and adopted by many contemporary European theorists and composers. It seems that also Michael Praetorius (1571-1621), who planned to discuss Zarlino's ideas in depth in his unfortunately never published volume IV of Syntagma musicum, was among them. Albeit often marginally and in passing, theoretical issues are also discussed in all three published volumes of Praetorius's encyclopaedic treatise. The aim of this article is to establish to what extent and in what way Praetorius adopted Zarlino's views on the modes.

\section{Glarean and Zarlino}

The question of the modes was one of the key issues discussed by Renaissance music theorists. ${ }^{1}$ It was an especially challenging one for the following reasons: (1) Renaissance music theorists took as their model the ancient philosophers' views on music. However,

1 The scope of the present paper is far too narrow to include a more detailed outline of the subject. 
the extant ancient writings on tonal systems that emerged at rather long (in some cases, centuries-long) intervals, turned out to be discordant and - after the lapse of so many centuries - quite difficult to understand. It seems that Renaissance theorists, especially early in the era, were often unaware of the fact that during their millennial history ancient music and the core concepts of ancient music theory were necessarily developing (i.e., changing) as well, making it almost impossible to observe them as a unified system. (2) The second problem was created by the Renaissance theorists themselves by assuming that the modern system of modes should be modelled on its ancient predecessor: they devoted much effort to searching for ways of tying the medieval apparatus of eight modes with the ancient systems of tonoi and harmoniai. Following the Humanist re-readings of the ancient sources, an awareness that the ancient tonal system (constructed for the circumstances of a distant age whose musical language completely differed from the Renaissance polyphony) could not be an everlasting, unalterable canon only gradually took root. (3) The third problem arose from Renaissance musical practice: besides the traditional eight modes with finals on $\mathrm{d}$, e, f and $\mathrm{g}$, ones with finals on $\mathrm{c}$ and a were becoming used with increasing frequency. Accordingly, a way to include the latter two in the system had to be found. ${ }^{2}$

As is well known, the system of twelve modes was first presented by the Swiss theorist Heinrich Glarean (1488-1563), who conceived it with the express aim of reviving the ancient tonoi. In the last chapter of the first book of his Dodecachordon (1547), he is critical of contemporary authors, and especially of Franchino Gaffurio. Glarean writes that he could hardly wait to obtain a copy of Gaffurio's treatise De harmonia instrumentorum musicorum opus and was eager to read it. However, when he studied the chapter dealing with modes, he remained disappointed, for Gaffurio, who remained loyal to the eight-mode system, was apparently unfamiliar with all the relevant sources and, moreover, had even misunderstood those he had read. ${ }^{3}$ That said, Glarean continues to compare the views of various ancient theorists and concludes that in constructing his own system, he will follow the Greek theorist Aristoxenus (fourth century BC) by proposing six principal (authentic) and six plagal modes. ${ }^{4}$ Through his construction of a twelve-mode system in which modes were designated by the ancient names Glarean accomplished two things: in his own view, he was reviving the system of ancient Greek tonoi as it had actually existed, ${ }^{5}$ and at the

For a general overview, see Powers et al., "Mode. III. Modal theories and polyphonic music"; Wiering, The Language of the Modes; and Judd, "Renaissance modal theory".

2 For detailed discussions of the debate around adopting the ancient systems of tonoi and harmoniai in the Renaissance and the advocacy of modes with finals on $\mathrm{c}$ and a, see Palisca, Music and Ideas, 71-98 (chapter "Humanist Revival of the Modes and Genera") and Palisca, Humanism in Italian Renaissance Musical Thought, 280-332 (chapter "Greek Tonality and Western Modality"). See also Powers et al., "Mode. III. Modal theories and polyphonic music".

3 Glarean, Dodecachordon I, 97-98.

4 Ibid., 102.

5 Within his extant writings Arostoxenus's system of tonoi is not fully explained; it is only in the works of several later authors that it is described in detail. (Cleonides, for example, also lists the tonoi's order and their names.) On the basis of Aristoxenus's Harmonica stoicheia and some of the later theorists' writings one may assume that he saw the tonoi as the placements of (one 
same time, he was successfully including within the system the modes with finals on c and a. Glarean's system of modes is presented in the table below.

\section{Table 1}

\begin{tabular}{|r|l|c|c|c|}
\hline No. & Name & F & A & A/P \\
\hline 1. & Dorian & $\mathrm{d}$ & $\mathrm{d}-\mathrm{d}$ & $\mathrm{A}$ \\
\hline 2. & Hypodorian & $\mathrm{d}$ & $\mathrm{a}-\mathrm{a}$ & $\mathrm{P}$ \\
\hline 3. & Phrygian & $\mathrm{e}$ & $\mathrm{e}-\mathrm{e}$ & $\mathrm{A}$ \\
\hline 4. & Hypophrygian & $\mathrm{e}$ & $\mathrm{h}-\mathrm{h}$ & $\mathrm{P}$ \\
\hline 5. & Lydian & $\mathrm{f}$ & $\mathrm{f}-\mathrm{f}$ & $\mathrm{A}$ \\
\hline 6. & Hypolydian & $\mathrm{f}$ & $\mathrm{c}-\mathrm{c}$ & $\mathrm{P}$ \\
\hline 7. & Mixolydian & $\mathrm{g}$ & $\mathrm{g}-\mathrm{g}$ & $\mathrm{A}$ \\
\hline 8. & Hypomixolydian & $\mathrm{g}$ & $\mathrm{d}-\mathrm{d}$ & $\mathrm{P}$ \\
\hline 9. & Aeolian & $\mathrm{a}$ & $\mathrm{a}-\mathrm{a}$ & $\mathrm{A}$ \\
\hline 10. & Hypoaeolian & $\mathrm{a}$ & $\mathrm{e}-\mathrm{e}$ & $\mathrm{P}$ \\
\hline 11. & Ionian & $\mathrm{c}$ & $\mathrm{c}-\mathrm{c}$ & $\mathrm{A}$ \\
\hline 12. & Hypoionian & $\mathrm{c}$ & $\mathrm{g}-\mathrm{g}$ & $\mathrm{P}$ \\
\hline
\end{tabular}

$\mathrm{F}=$ finalis

$\mathrm{A}=$ ambitus

$\mathrm{A} / \mathrm{P}=$ authentic/plagal mode

A discussion of the modes occupies an important place likewise in Zarlino's Istitutioni harmoniche (published a mere eleven years after the Dodechachordon) as the main topic of book 4. Unlike his predecessors, Zarlino rushes to explain the differences between the modern and ancient concepts already in his basic definitions. In general, "mode" is defined as reason (ragione), or as that measure or form (misura oforma) which prevents one from going too far in what one does: in this way, everything is done with a certain "middle-of-the-road" approach (mediocrità) and moderation (moderazione). If this order is accidentally (or deliberately) disrupted, this will very severely affect our senses. ${ }^{6}$ Ancient musicians had also been aware of this principle, Zarlino maintains, and it is for that very reason that they named their compositions "modes". Within them, rhythm (numeri) or metre (metri) 7 and harmonies were united in just proportions, such that these compositions could express various themes. However, when discussing individual harmoniai, they called them similarly "modes", supplementing this description with adjectives such as "Dorian" or "Phrygian", in accordance with the name of the people that had invented them. Each individual harmonia had its own characteristics (e.g., severe, serious, bac-

and the same) tonal system (scale) on particular pitches. (For a detailed explanation, see Barker, Greek Musical Writings II, 131, and Bélis, “Aristoxenus".) Indeed, Arostoxenus's tonoi had a function completely different from Renaissance modes: the former are a kind of transposition of the same system to different pitches, whereas the latter are actually different systems (pitch sequences) distinguished by their characteristic disposition of whole tones and semitones.

6 Zarlino, Istituzioni armoniche, 610-611.

7 He refers here to the rhythm or metre of the text (the poetic foot). 
chanalian, virtuous), was associated with particular rhythms and was suitable for setting a particular kind of textual content to music. ${ }^{8}$

Taking the above into consideration, it is evident that, according to Zarlino, ancient modes were not mere forms of scales, but were conceived of much more broadly. In the first, broader sense they were understood as a proportionate, orderly union of text, music (harmonia) and metric rhythm (numero). In this instance, "mode" stands for a vocal composition, or that to which Plato, in his Republic, gave the name melos. ${ }^{9}$ Only in the second, narrower sense is "mode" also understood as harmonia, meaning the distinctive component of vocal composition that is music (as distinct from text).

Zarlino emphasizes that there is a difference in the case of modern music. Contemporary musicians, too, employ a kind of order, but only insofar as this is present in one of the octave species: this sequence (ordine) of singing in different manners (maniera) or with different melodies (aria) is "mode", which is also called by some people "trope" (tropo) or "tone" (tuono). ${ }^{10}$ Therefore, contrary to the practice of ancient times, the meaning of "mode" in Zarlino's time is limited to the order (sequence of notes) within particular octave species, meaning it actually stands for musical scales.

In his Istitutioni Zarlino begins by discussing the ancient modes. In doing so, he does not attempt to discover or devise a unified system; rather, his presentation is a (sometimes incoherent) compilation of views and statements taken from several ancient authors. As he repeatedly explains, there is much confusion in this area, which makes it difficult to see things as they truly once were. ${ }^{11}$ Despite the in-depth nature of Zarlino's study and his knowledge of the content of many ancient treatises on music, the reader of the Istitutioni who looks at the chapters dealing with the ancient modes sometimes gets the feeling that the author did not fully understand some of ancient Greek music theory's key concepts. Furthermore, as Zarlino lists the views of various ancient authors almost without criticism (unlike his typical approach in the Istitutioni), it seems that in many cases, he did not even try to understand them; rather, he consciously left contradictory passages open in meaning and unexplained. However, as it turns out, this was not at all important for his discussion of the modern modes: "Whatever the order of the ancient modes had been, whatever their number had been and whatever they had been named according to the ancient theorists, this is of little importance for us [modern musicians]", Zarlino maintains. ${ }^{12}$ He argues that the use of the ancient modes (which was completely different from that of the modern ones) has over time died out, making it impossible to find any certain trace of it in the music of his own age. This is not surprising at all, however, since time consumes everything created (tempo consuma ogni cosa creata); more surprising is the belief of some fools (sciocchi) who are convinced that they are still using the

8 Zarlino, Istituzioni armoniche, 611-612.

9 Plato, The Republic, III, 398c-e, 87-88. Zarlino was familiar with Plato's concept of melos and elsewhere in Istitutioni, he also presented it with the same content he used to define "mode" here. (See Zarlino, Istitutioni armoniche, 601, 708.)

${ }^{10}$ Zarlino, Istituzioni armoniche, 623.

${ }^{11}$ See, for example, ibid., 629.

${ }^{12}$ Ibid., 629. 
chromatic and enharmonic genera, even though these have long since been abandoned. In holding that conviction, they are unaware that they have no proper knowledge even of the diatonic genus, Zarlino concludes. ${ }^{13}$

Following the presentation of the ancient modes, the discussion in Istitutioni turns to the modern ones. Here, too, their origins and inventors are the first thing to be discussed. ${ }^{14}$ This preamble is then followed by a detailed and more cogent presentation of the system. Zarlino explains that there are twelve modern modes and that they can be constructed in two ways: via the joining together of different species of fourth and fifth, or via the harmonic and arithmetic division of the octave. Both methods are demonstrated in the examples below.

\section{Example 1}

Joining the species of fifth to the species of fourth.

a) Joining the first species of fifth to the three species of fourth.
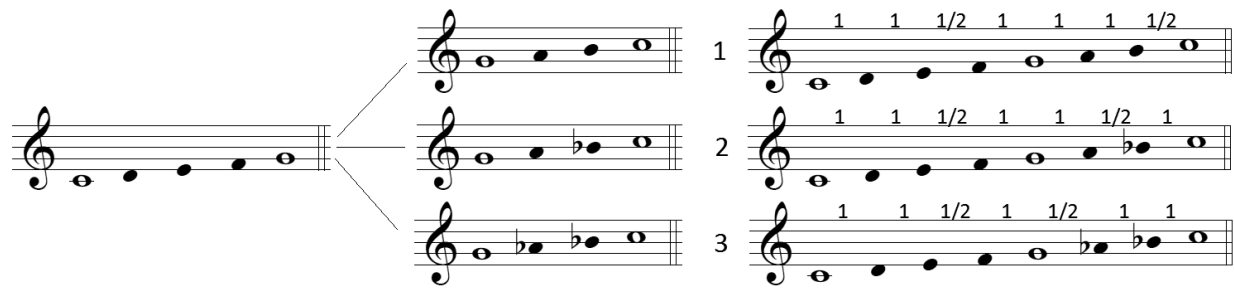

b) Joining the second species of fifth to the three species of fourth.
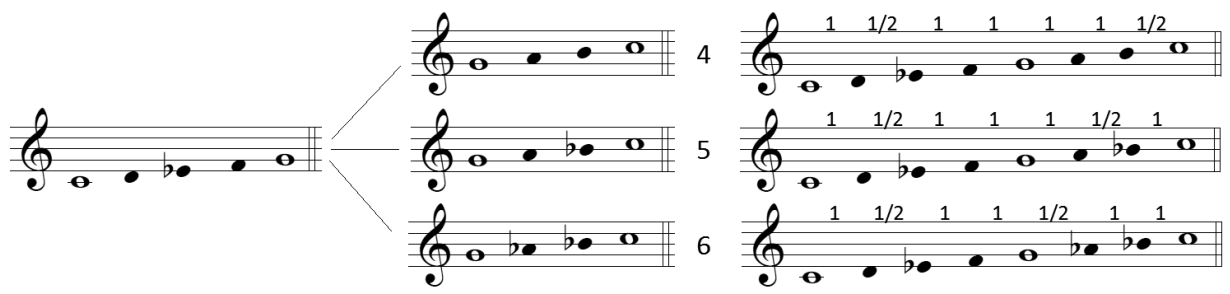

13 Ibid., 630 .

${ }^{14}$ In the end, this discussion actually takes the form of a short history of church music of the Latin West. In accordance with well-known traditional beliefs, Zarlino explains that the Gregorian chant was organized and systematized by Pope Gregory I (590-604), while Pope Vitalian (657-672) is supposed to have been the person who introduced organum in consonances into singing. Besides these two, Popes Leo II (682-683) and Damasus I (366-384) were also important, the former for composing chant melodies for the psalms and reordering the hymns, and the latter for introducing antiphonal psalmody. Some argue that the modes were invented by Pope Gregory I himself; however, Zarlino ascertains, from what we know about the history of ecclesiastical chant their inventor cannot be determined. He adds that it is likewise impossible to determine anything about the invention of the modern manner of composing; we know only that - by comparison with church music - it was only recently invented (Zarlino, Istituzioni armoniche, 630-632). 
Example 1 (continued)

c) Joining the third species of fifth to the three species of fourth.

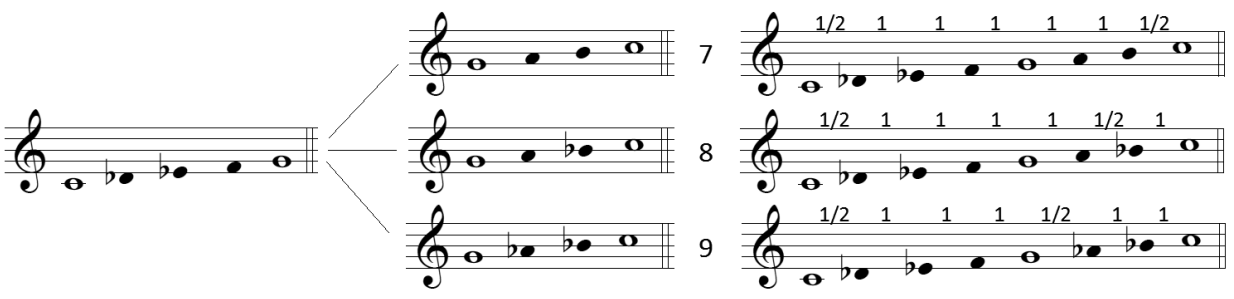

d) Joining the fourth species of fifth to the three species of fourth.

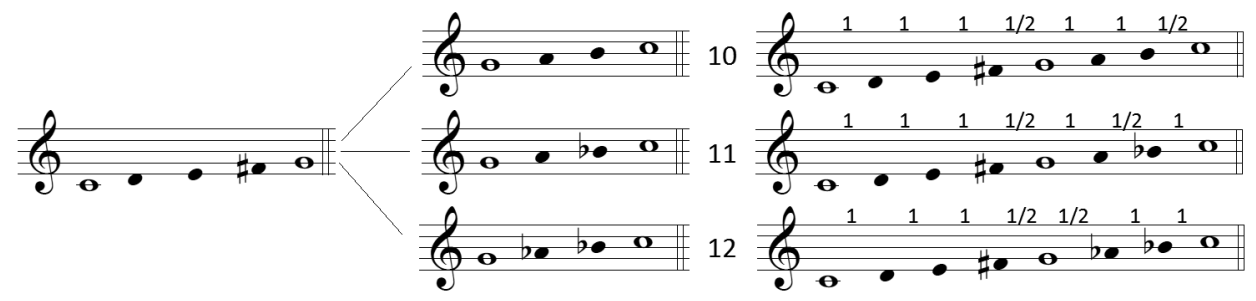

\section{Example 2}

Joining the species of fourth to the species of fifth.

a) Joining the first species of fourth to the four species of fifth.
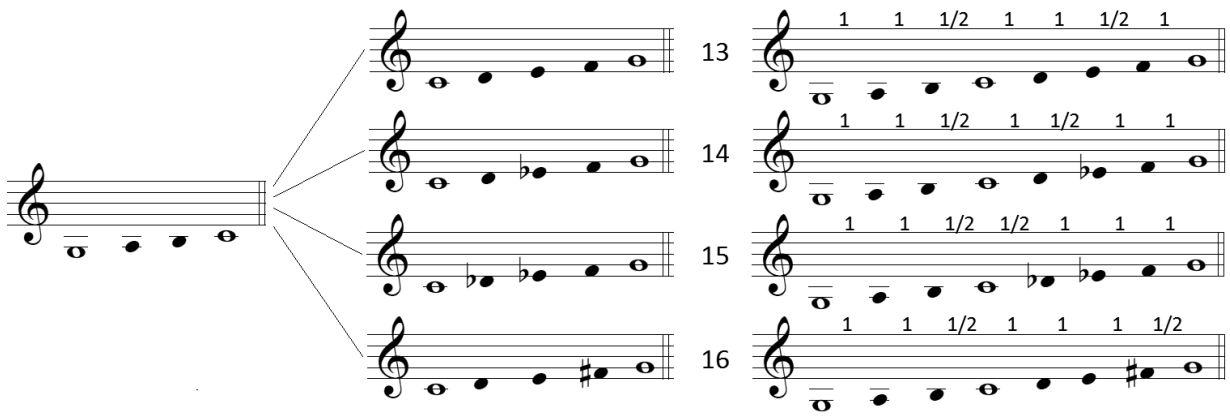

b) Joining the second species of fourth to the four species of fifth.

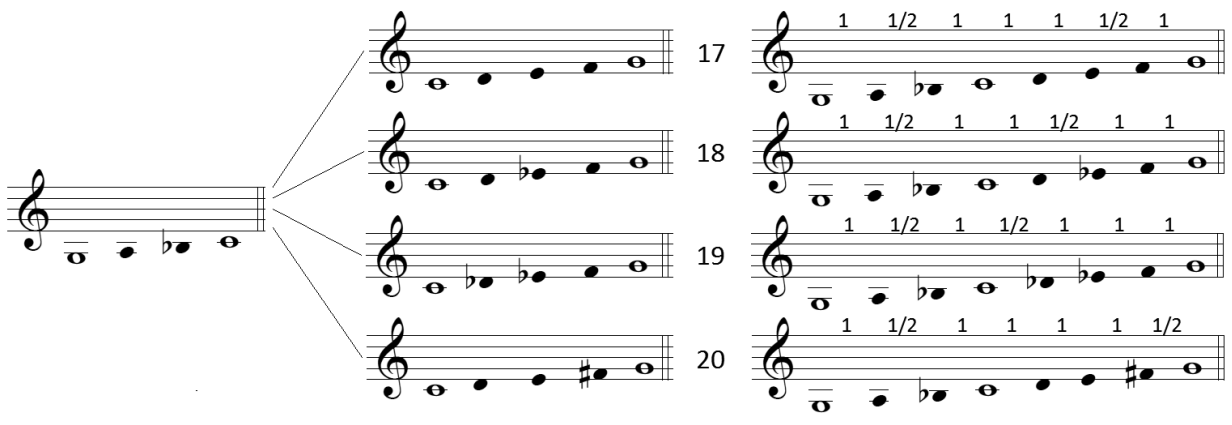


Example 2 (continued)

c) Joining the third species of fourth to the four species of fifth.
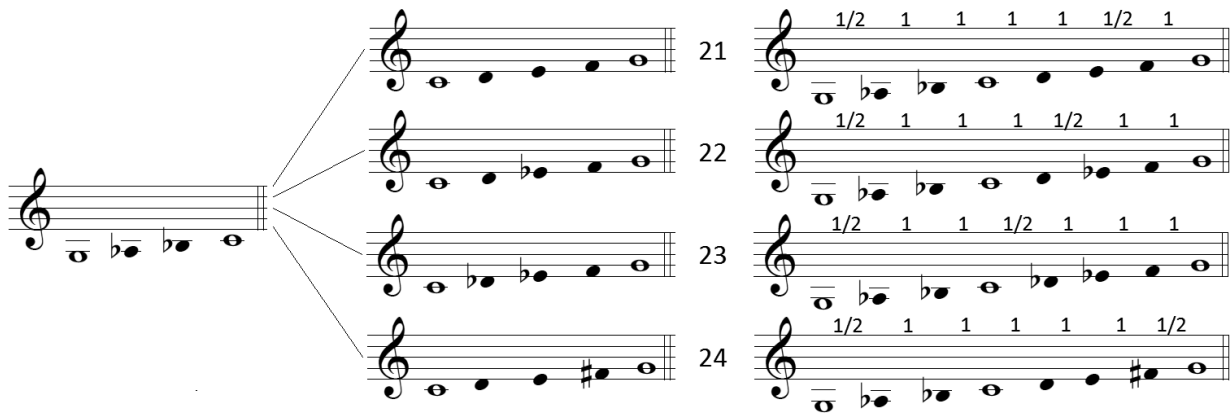

22

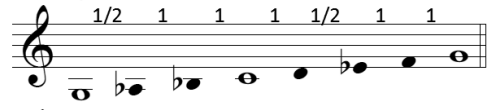

23

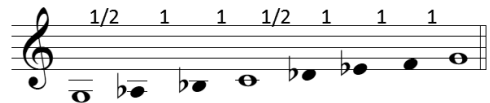

24

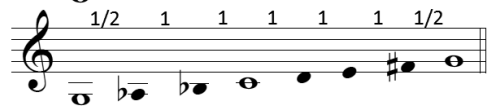

As a result of combining the species of fifth and fourth, twenty-four different octave combinations emerge; however, there are only twelve modes. In his Istitutioni Zarlino neither mentions all of the possible combinations nor explains according to which criteria the twelve among them that produce modes are chosen. He is content to show which species of fifth and fourth are employed and in what manner they are joined for individual modes (fifth + fourth or fourth + fifth), offering only a general explanation that other combinations are not possible. ${ }^{15}$ In this respect, Zarlino's construction of the twelve-mode system based on joining together the species of fifth and fourth is inadequate. We must therefore turn to Glarean, from whom Zarlino has taken the system, for clarification. In chapter 3 of book 2 of the former's Dodecachordon, four criteria are listed, in accordance with which twelve out of the twenty-four possible combinations have to be discarded: (1) There are four consecutive whole tones in the series. (2) There are five consecutive whole tones in the series. (3) Between two semitones, there lies only one whole tone. (4) There are two consecutive semitones in the series. ${ }^{16}$ Following the stated criteria, numbers 3,4 , $7,8,11,12,14,15,19,20,21$ and 24 of the above figures must be discounted, leaving the remaining twelve combinations to constitute the twelve modes.

In the second manner of constructing the twelve modes the starting points are the species of the octave, which can be divided either harmonically or arithmetically. ${ }^{17}$

${ }^{15}$ Zarlino, Istituzioni armoniche, 653-655.

${ }^{16}$ Glarean, Dodecachordon I, 106.

${ }^{17}$ When speaking about the harmonic and arithmetic division of the octave species, Zarlino actually has in mind the determination of the arithmetic or harmonic mean of the interval of an octave. In his Istitutioni interval is defined as the distance between two different notes, the lower and the higher, which is mathematically expressed by a ratio: as is well known, the octave is defined by the ratio $2: 1$. Since the intervals are expressed by ratios, Zarlino argues that they can also be divided in the same way; in the Istitutioni both the arithmetic and the harmonic divisions of a given ratio are explained in detail. The arithmetic mean of a given ratio is determined by adding together both its terms and then dividing the result by two. If the ratio is reduced to its lowest terms (making these terms relatively prime), the procedure described is impossible to perform without using decimals, which, Zarlino warns, are not acceptable to the arithmetician. In this case, the ratio's terms need to be doubled before performing the procedure. So the arithmetic mean of the ratio of the octave $(2: 1)$ is determined by first doubling its terms and obtaining a ratio of $4: 2$. Then both terms are added together $(4+2=6)$, and the result is divided by 
According to Zarlino, the first, which divides the octave into a fifth and a fourth, is very good and pleasant (molto buona e soave), while the second, which divides the octave into a fourth and a fifth, sounds somewhat worse (non essendo in tutto sonora). ${ }^{18}$ Since there are seven octave species, there are theoretically fourteen possible divisions. However, two of them can immediately be discarded: (1) The octave $b-b$ cannot be divided harmonically, since there is no perfect fifth above the tone $b$ within the diatonic scale ( $b-f$ is a diminished fifth). (2) The octave $\mathrm{f}-\mathrm{f}$ cannot be divided arithmetically, since there is no perfect fourth above the note $\mathrm{f}$ within the diatonic scale ( $\mathrm{f}-\mathrm{b}$ is an augmented fourth). So six harmonic and six arithmetic divisions of the octave can be made, a total of twelve:

\section{Example 3}

Six harmonic divisions of the octave

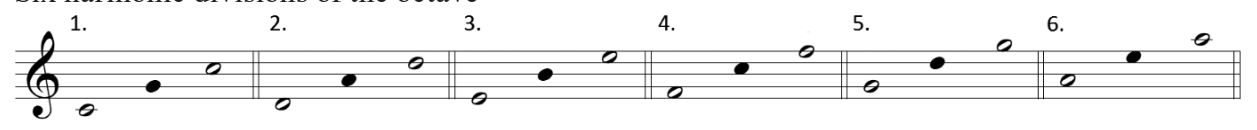

\section{Example 4}

\section{Six arithmetic divisions of the octave}

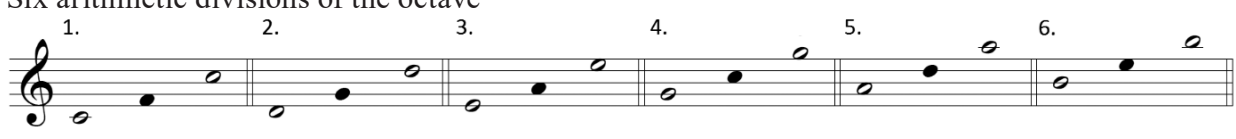

Both methods of constructing modes are important for Zarlino's further discussion, particularly for determining some of the characteristics of the modes. On the basis of the harmonic and arithmetic divisions of the octave, the modes can be divided into principal (principali) or authentic, and lateral (laterali) or plagal. The first are described as principal because they were considered more noble, being a product of the harmonic

two $(6: 2=3)$. The result is a proportion of $4: 3: 2$, by which an arithmetic mean has been determined for the interval of an octave, dividing it neatly into a fourth $(4: 3)$ and a fifth $(3: 2)$. The harmonic mean of a given ratio is determined by placing a third term between its two initial terms in such a way that the ratio of the outer terms equals the ratio of the differences between the terms of the two inner ratios. This is done by first determining the arithmetic mean of a given ratio. Then the outer terms both have to be multiplied by the middle one, and the resulting products will be the outer terms of the desired harmonic ratio. Finally, we obtain the middle term by multiplying the outer terms of the arithmetic proportion among themselves. So the harmonic mean of the ratio of the octave $(2: 1)$ is determined by first finding its arithmetic mean: $4: 3: 2$. Then both external terms have to be multiplied by the middle one $(4 \cdot 3=12$ and $2 \cdot 3=6)$ and among themselves $(4 \cdot 2=8)$. The result is the harmonic proportion $12: 8: 6$ or $6: 4: 3$, for which the given rule applies: the ratio of the outer terms $(12: 6$ or $2: 1)$ equals the ratio of the differences of the terms of both inner ratios $(12-8=4,8-6=2 ; 4: 2=2: 1)$. Through the harmonic proportion a harmonic mean is thereby determined for the octave interval, dividing it into a fifth $(6: 4=3: 2)$ and a fourth (4:3). See especially Zarlino, Istituzioni armoniche, 104-105, 110-112, 185 and 207.

${ }^{18}$ Zarlino, Istituzioni armoniche, 651. 
division of the octave rather than the less noble arithmetic one. In contrast, the lateral modes are a product of the arithmetic division of the octave. ${ }^{19}$

Being aware of the alternative method of forming modes - that is, by joining together the species of fifth and fourth - is, on the other hand, important for determining their finals and compass (ambitus). The final (finalis) is the lowest note of the fifth of which a mode is composed, regardless of whether the fourth is above or below it. ${ }^{20}$ Consequently, the authentic and plagal modes employing the same fifth share the same final: $\mathrm{c}$ is the final of the first and second modes, $d$ of the third and fourth modes, e of the fifth and sixth modes, $f$ of the seventh and eighth modes, $g$ of the ninth and tenth modes, and a of the eleventh and twelfth modes. However, even if their finalis is the same, the authentic and plagal modes differ in compass. The compass of the plagal modes goes from the fourth below the final to the fifth above it; only occasionally does it overshoot the fifth above the final by a whole tone or semitone. Conversely, the ambitus of the authentic modes rises to the octave above the final and only occasionally will this compass be extended by a whole tone or a semitone below it. The modes that comply with this compass are known as perfect (perfetti), but exceptions are also possible. If the authentic modes extend their ambitus downwards, or the plagal ones extend it upwards, they are called "superfluous" (superflui). If, in contrast, they do not reach the lowest or highest note of their octaves, they are called "imperfect" or "diminished" (diminuti). ${ }^{21}$ A combination of both exceptions is also possible: if the plagal mode extends its ambitus upwards by four notes, and if the authentic mode's compass is extended by the same number of notes downwards, these two modes will be termed "united" (communi), since in this case their compass comprises exactly the same eleven notes. ${ }^{22}$

After defining the modes, presenting the two possible ways of constructing them and explaining some of their characteristics, Zarlino continues with a detailed discussion of each individual mode. ${ }^{23}$ His system of modes is summarized in the Table 2.

Table 2

\begin{tabular}{|c|l|l|l|l|l|l|}
\hline No. & (Name) & F & AS & A/P & NRC & Characteristics \\
\hline 1. & (Ionian) & c & $\mathrm{c}-g-\mathrm{c}$ & $\mathrm{A}$ & $\mathrm{c}, \mathrm{e}, \mathrm{g}$ & $\begin{array}{l}\text { Lascivious. Suitable for dances; most dances } \\
\text { in Italy are played in this mode. }\end{array}$ \\
\hline 2. & (Hypoionian) & $\mathrm{c}$ & $\mathrm{g}-\mathrm{c}-\mathrm{g}$ & $\mathrm{P}$ & $\mathrm{g}, \mathrm{c}, \mathrm{e}$ & $\begin{array}{l}\text { In its original form it is cheerful. Transposed } \\
\text { up a fourth, it is suitable for expressing } \\
\text { thoughts of love that contain dolorous things. }\end{array}$ \\
\hline 3. & (Dorian) & $\mathrm{d}$ & $\mathrm{d}-\mathrm{a}-\mathrm{d}$ & $\mathrm{A}$ & $\mathrm{d}, \mathrm{f}, \mathrm{a}$ & $\begin{array}{l}\text { Innumerable sacred compositions are written } \\
\text { in this mode. Its effect lies between sad and } \\
\text { cheerful. It is best employed for setting words } \\
\text { that are full of gravity and deal with lofty and } \\
\text { edifying things. }\end{array}$ \\
\hline
\end{tabular}

19 Ibid., 659.

${ }^{20}$ Ibid., 660 .

${ }^{21}$ Ibid., 662.

22 Ibid., 663.

${ }^{23}$ Ibid., 676-702. The available English translation was also consulted here; see Zarlino, On the Modes, 54-89. 
Table 2 (continued)

\begin{tabular}{|c|c|c|c|c|c|c|}
\hline No. & (Name) & $\mathbf{F}$ & AS & $\mathbf{A} / \mathbf{P}$ & NRC & Characteristics \\
\hline 4. & (Hypodorian) & d & $\mathrm{a}-d-\mathrm{a}$ & $\mathrm{P}$ & $a, f, d$ & $\begin{array}{l}\text { Tearful and humble. Fit for words that } \\
\text { represent weeping, sadness, loneliness, } \\
\text { captivity, calamity and every kind of misery. }\end{array}$ \\
\hline 5. & (Phrygian) & $\mathrm{e}$ & $\mathrm{e}-b-\mathrm{e}$ & A & $e, g, b$ & $\begin{array}{l}\text { Moves one to weeping. Fit for words that are } \\
\text { tearful and full of lamentation }\end{array}$ \\
\hline 6. & (Hypophrygian) & $\mathrm{e}$ & $\mathrm{b}-e-\mathrm{b}$ & $\mathrm{P}$ & $b, e, g$ & $\begin{array}{l}\text { Suited to lamenting words or subjects that } \\
\text { contain sadness or supplicatory lamentation } \\
\text { (lamentazione supplichevole), such as matters } \\
\text { of love, and to words that express languor, } \\
\text { quiet, tranquillity, adulation, deception and } \\
\text { slander. Some have called it a flattering mode. } \\
\text { It is sadder than its principal counterpart. }\end{array}$ \\
\hline 7. & (Lydian) & $\mathrm{f}$ & $\mathrm{f}-c-\mathrm{f}$ & A & $f, a, c$ & $\begin{array}{l}\text { Brings modesty, happiness and relief from } \\
\text { annoying cares to the spirit. To be used for } \\
\text { words that deal with victory. It is joyous, } \\
\text { modest and pleasing. }\end{array}$ \\
\hline 8. & (Hypolydian) & f & $\mathrm{c}-f-\mathrm{c}$ & $\mathrm{P}$ & $c, a, f$ & $\begin{array}{l}\text { Frequently used by church composers. Not } \\
\text { cheerful or elegant and therefore used in } \\
\text { serious and devout compositions containing } \\
\text { commiseration and fitted to matters containing } \\
\text { tears. Called a devout and tearful mode. }\end{array}$ \\
\hline 9. & (Mixolydian) & g & $\mathrm{g}-d-\mathrm{g}$ & A & $g, b, d$ & $\begin{array}{l}\text { Appropriate for lascivious words, for those } \\
\text { which are cheerful and spoken with modesty, } \\
\text { and those which express threat, perturbation } \\
\text { and anger. }\end{array}$ \\
\hline 10. & (Hypomixolydian) & $\mathrm{g}$ & $\mathrm{d}-g-\mathrm{d}$ & $\mathrm{P}$ & $\mathrm{d}, \mathrm{g}, \mathrm{b}$ & $\begin{array}{l}\text { Contains a certain natural softness and an } \\
\text { abundant sweetness that fills the spirits of the } \\
\text { listeners with joy combined with great gaiety } \\
\text { and sweetness. It is completely removed from } \\
\text { lasciviousness and every vice. }\end{array}$ \\
\hline 11. & (Aeolian) & $\mathrm{a}$ & $\mathrm{a}-e-\mathrm{a}$ & A & $\mathrm{a}, \mathrm{c}, \mathrm{e}$ & $\begin{array}{l}\text { Open and terse, very suitable for lyric poetry. } \\
\text { To be used with words containing cheerful, } \\
\text { sweet, soft and sonorous subjects, because } \\
\text { it possesses a pleasant severity, mixed with } \\
\text { a certain cheerfulness and sweet softness. }\end{array}$ \\
\hline 12. & (Hypoaeolian) & $\mathrm{a}$ & $\mathrm{e}-a-\mathrm{e}$ & $\mathrm{P}$ & e, c, a & $\begin{array}{l}\text { Used in many sacred compositions. Similar } \\
\text { in nature to the } 4 \text { th and } 6 \text { th modes. }\end{array}$ \\
\hline
\end{tabular}

$\mathrm{F}=$ finalis

$\mathrm{AS}=$ ambitus and structure

$\mathrm{A} / \mathrm{P}=$ authentic/plagal mode

$\mathrm{NRC}=$ notes of regular cadences ${ }^{24}$

If the system of modes presented above is compared with Glarean's (from whom Zarlino derived it), two differences in particular may be noted: (1) the order of the modes

${ }^{24}$ Cadences are classified as "regular" and "irregular" by Zarlino. Regular ones are placed on the degrees I, III, V and VIII, whereas all the others are irregular. For a detailed account, see Zarlino, Istituzioni armoniche, 676. 
(or their numbering) is different, and (2) the modes are not called by their ancient names, but only numbered (which is why, in the above table, the names from Glarean's system are used and written in brackets). The reasons for both departures from the model are explained by Zarlino himself.

In the first edition of the Istitutioni (1558), the order of the modes corresponds to Glarean's; it was only in the second edition (1573) that Zarlino changed it. However, in the Istitutioni the reasons for this important change are - somewhat surprisingly - not explained. Thus, one must consult the 1571 edition of Zarlino's Dimostrationi harmoniche for clarification, as this is where the new order of the modes was actually introduced. First, in the eighth "definition" of the fifth "conversation", a new ordering of the octave species is established. Instead of the $\mathrm{d}-\mathrm{d}$ octave, the one with its semitones between the third and fourth and seventh and eighth degrees (that is, the c-c octave) was placed first. ${ }^{25}$ To justify the new order, Zarlino (1) first refers to his Istitutioni: there (in 1558), he had shown the division of the octave into whole tones and semitones according to the nature of the harmonic number. ${ }^{26}$ The result of this division was a sequence of tone-tone-semitone-tone-tone-tone-semitone, which occurs precisely in the c-c octave; accordingly, this octave species should undoubtedly occupy the first place since it is the most "natural" of all. ${ }^{27}$ (2) The second reason is related to the hexachord system. Here, the syllables are Ut-Re-Mi-Fa-Sol-La, making it completely incomprehensible for the first type of octave to begin on the second syllable, Re. It was also for this reason that Zarlino had to make the change and choose the octave species beginning with the syllable Ut, and at the same time with the note c, as first. (3) By this means - Zarlino's third reason - the octave species may follow one another without interruption. ${ }^{28}$ (4) The fourth reason for the change is finally connected directly to the modes: making the change also allows the series of modes to be arranged in accordance with the natural and uninterrupted sequence. (5) In addition (Zarlino's fifth reason), by this means a hexachord will be formed between the

${ }^{25}$ Zarlino, Dimostrationi harmoniche, 245-246.

${ }^{26}$ In the Istitutioni the division of the octave into tones and semitones with the employment of harmonic proportion is carried out as part of Zarlino's advocacy for perfection of syntonic diatonic tuning. See Zarlino, Istituzioni armoniche, 255-260.

${ }^{27}$ Zarlino, Dimostrationi harmoniche, 246.

${ }^{28}$ It is explained that the first species of octave was originally placed on A, which in Guido's system of hexachords corresponds to the solmization syllable Re (in the hexacordum durum). However, it was quickly noticed that in this case, the octave species cannot follow one after the other without interruption, since the octave $\mathrm{b}-\mathrm{b}$ is unsuitable for use because of its diminished fifth; hence the sequence of the octave species would have to be interrupted between A and C. So instead of $\mathrm{A}$, the note $\mathrm{D}$ was chosen as the starting point, which is similarly denoted by the syllable $\mathrm{Re}$ (in this instance in the hexachordum naturale). Nevertheless, this order has to be rejected as well, since, again, the octave $\mathrm{c}-\mathrm{c}$ cannot be included in it without causing an interruption between a and c (Zarlino, Dimostrationi harmoniche, 247). Zarlino's explanation of this is somewhat unclear: he is here speaking of octave species, of which there are necessarily seven, since the octave $b-b$ is likewise an octave species. In this context the sequence of octave species will in no eventuality be interrupted. The octave $b-b$ is, in fact, unsuitable only as a basis for a mode, which means that in this case, only the sequence of modes (about which he speaks in the next, fourth reason) - but not the sequence of octave species - would be interrupted. 
strings of their finals: c-d-e-f-g-a (Ut-Re-Mi-Fa-Sol-La). ${ }^{29}$ (6) Zarlino saw the sixth (and final) reason for renumbering the modes in approaching the ancient tradition: within a system thus conceived, the first three authentic modes (with their finals on $\mathrm{c}, \mathrm{d}$ and e) will be a whole tone (major second) apart, just like the three central and predominant ancient modes: the Dorian, Phrygian and Lydian. ${ }^{30}$ Finally, in his fourteenth "definition" of the same "conversation", the octave species are affiliated with particular modes: the first octave species contains the first mode, the second octave species contains the third mode, and so on. ${ }^{31}$

It appears that Zarlino's renumbering of modes should be seen, above all, as a part of his ever-present desire to form a consistent and orderly system. Unlike Glarean's order, his newly established sequence is connected to both of the key Istitutioni concepts, the syntonic diatonic tuning and the concept of "sounding number", as well as with the hexachord system, which was of great importance for contemporary musical practice. In addition, Zarlino's renumbering eliminates the anomalies: in such a (natural) sequence the species of octave, the modes based on them and their final notes can follow uninterruptedly one after the other (taking into account the fact that $\mathrm{b}$ is not allowed to function as a final).

Somewhat clearer is Zarlino's argument for giving - or, rather, not giving - names to the modes. It originates from his criticism of contemporary theorists, who were incorrectly describing the three modes with their final notes on $\mathrm{d}$, e and $\mathrm{f}$ as Dorian, Phrygian and Lydian. On this point, the ancient authors are unanimous: these three modes were a whole tone apart (i.e., the Dorian from the Phrygian, and the Phrygian from the Lydian), ${ }^{32}$ which is not the case when the Dorian mode is placed on $\mathrm{d}$, since there is then a semitone between e and $\mathrm{f}$. So to use the correct ancient names, the first mode in their system (on c) should be Dorian, the third (on d) Phrygian, and the fifth (on e) Lydian; ${ }^{33}$ only in this way would their finals be separated by a whole tone. ${ }^{34}$ All in all (so Zarlino argues), a lot of confusion results from calling the modes by the ancient nomenclature, which modern authors use incorrectly. For this reason, and because there is absolutely no connection

${ }^{29}$ Zarlino, Dimostrationi harmoniche, 247.

${ }^{30}$ Ibid., 248.

31 Ibid., 251.

${ }^{32}$ Among others, Ptolemy speaks of this (see Barker, Greek Musical Writings II, 336).

${ }^{33}$ In the first edition of the Istitutioni (1558), which follows Glarean's system strictly, the listed modes are marked as eleventh (Glarean places it on c), first (Glarean places it on d) and third (Glarean places it on e). Zarlino, Istitutioni harmoniche, 1558, 308.

${ }^{34}$ Zarlino, Istituzioni armoniche, 650. This statement by Zarlino is inaccurate: some other modes are similarly a whole tone apart - for example, the fifth, seventh and ninth (with their finals f, $\mathrm{g}$, a). As was the case with renumbering the modes, a more detailed discussion of their names reappears in the Dimostrationi harmoniche. From this discussion, too, it emerges clearly that for the modern modes correct numbering is far more important than any attempt to call them by their ancient names. If, however, they had for some reason to be called by these ancient names, the first three authentic modes (with finals c, d and e according to Zarlino's renumbering) should be called Dorian, Phrygian and Lydian (being a whole tone apart), and after that, the Mixolydian, Ionian and Aeolian modes would follow, with finals $\mathrm{f}, \mathrm{g}$ and a (Zarlino, Dimostrationi harmoniche, 252). 
between the modern and ancient modes, Zalino concludes that he, for his part, will designate them only by consecutive numbers. ${ }^{35}$

How should Zarlino's discussion of the modes as presented in the Istitutioni be viewed after the survey just concluded? On the one hand, the modern and ancient modal systems are very clearly distinguished. Even though it appears that Zarlino did not fully comprehend some of the ancient music theorems, he is, nevertheless, aware that the ancient modes differed from the modern ones - a fact that he took care to stress several times. In this recognition he differs from the majority of his Renaissance predecessors, who were instead looking for possibilities to merge the two. Accordingly, in the Istitutioni the ancient modes are presented as a relic of the past that, while certainly important, has nothing to do with contemporary musical practice. Zarlino adopted Glarean's system not because he considered that Glarean had revived the ancient modes (as the latter was convinced he was doing) or at least had tried to imitate them, but because Glarean's system (although slightly altered) was most suitable for describing and comprehending the musica practica of Zarlino's own time as he saw it. In this perspective, Zarlino's renumbering of Glarean's modes can be viewed as an attempt to perfect (rather than reject) the received system and place it within the all-embracing concept of the Istitutioni ${ }^{36}$ From a historical viewpoint,

${ }^{35}$ Zarlino, Istituzioni armoniche, 650.

${ }^{36}$ In his book Untersuchungen über die Entstehung der harmonichen Tonalität (also available in English translation as Studies on the Origin of Harmonic Tonality), Carl Dahlhaus suggests that Zarlino changed and redefined Glarean's system mainly because he wished "to cleanse the ancient tradition of medieval errors [and] tried to restore the ancient nomenclature to its original meaning", although he supposedly did not understand the ancient system well enough. According to Dahlhaus, Zarlino placed the mode with c as final in first position only because he was convinced that it was precisely this mode that corresponded to the ancient Dorian, the first of the three prominent ancient modes (Dahlhaus, Studies, 206-207). If one reads the chapters on modes in the Istitutioni and Dimostrationi and considers them in the broader context of both treatises, it is difficult to sustain such conclusion. It would appear that Dahlhaus drew his conclusions primarily on the basis of Zarlino's sixth reason for renumbering the modes, according to which the distances between the first three authentic modes in the newly established system coincide with the distances between the three main ancient modes. For Zarlino (who on several occasions emphasizes that the ancient modes were something completely different from the modern ones), this fact is undoubtedly important - but apparently only as additional confirmation of the accuracy of the renumbered system he had proposed. Far more important are the first five reasons, on the basis of which Glarean's system in its adapted form is firmly integrated into the all-embracing musical concept of the Istitutioni. Finally, the same can also be concluded from Zarlino's discussion in the Dimostrationi. After presenting and rationally affirming the first five reasons, the conversation turns away for a while from the subject of renumbering the modes, after which the sixth reason is introduced with the following words: "I would like to add one more reason to those already mentioned that led me to establish such a sequence, and which just now came into my mind" (Zarlino, Dimostrationi harmoniche, 248). From Zarlino's discussion it would seem that his thinking was quite contrary to what Dahlhaus attributed to him: he did not lead off with the mode on c because he considered it to be the ancient Dorian, but rather because, after realizing that the first three authentic modes in the system he had proposed (with finals on c, d and e) were a whole tone (major second) apart, he concluded that they should more properly have been called Dorian, Phrygian and Lydian, seeing that these three similarly named ancient modes were by the same interval apart. 
Zarlino's discussion of the ancient modes can be seen as one of the earliest attempts fully to present and systematize ancient ideas, thereby laying down a cornerstone on which his contemporaries and immediate successors could build.

On the other hand, there are also many similarities between Zarlino's modes and the ancient systems of tonoi and harmoniai, of which Zarlino was undoubtedly aware, even though he did not give them prominence. Outwardly, the most obvious connection is the fact that both Zarlino's modes and the ancient harmoniai (in the meaning of octave scales) were based on octave species or diverse sequels of whole tones and semitones within this fixed interval. Moreover, it is within this diversity that the characteristics of individual modes take shape, enabling music based on each of them to impart feelings to man and thereby inflect or even completely modify his mood. From this standpoint, Zarlino's modes are quite similar to the harmoniai discussed in Plato's Republic. They may be seen as a reservoir of notes out of which a composition is formed, and it is precisely the proportions between these notes that determine the composition's character. From this perspective, modes can in fact be understood as abstract forms (or "ideas") on which each particular composition is based.

\section{Calvisius and Praetorius}

From the Syntagma musicum it is not entirely clear whether Praetorius, who was undoubtedly familiar with Zarlino's musical-theoretical ideas, became acquainted with them directly, or perhaps indirectly, through the writings of some other contemporary German theorist such as Seth Calvisius (1556-1615). Calvisius provided a detailed presentation of his system of modes in his Exercitationes musicae duae (1600), where he clearly followed Zarlino's ideas, but with some deviations. Although Calvisius, too, speaks of twelve modes, it is clear from the content that in his perception, the authentic and plagal modes with the same final were merely two manifestations of one and the same mode. He explains that the main modes (modi principali), also called "authentic", are six (Ionian, Dorian, Phrygian, Lydian, Mixolydian, and Aeolian), each with its own duplicate (duplex). In the latter, the fifth from which they are constructed remains in place, while the position of the fourth changes. And because the fourth moves below the fifth in this case, these modes are also called "lower" (remissus) or "plagal" ${ }^{37}$ So Calvisius is likewise of the opinion that the modes are constructed from different species of fourth and fifth. In his Exercitationes all six possible combinations are listed:

Table 3

\begin{tabular}{|l|c|c|}
\hline Mode & $\begin{array}{c}\text { Species of } \\
\text { fifth }\end{array}$ & $\begin{array}{c}\text { Species of } \\
\text { fourth }\end{array}$ \\
\hline Ionian & $1 \cdot(1-1-1 / 2-1)$ & $1 \cdot(1-1-1 / 2)$ \\
\hline Dorian & $2 \cdot(1-1 / 2-1-1)$ & $2 \cdot(1-1 / 2-1)$ \\
\hline Phrygian & $3 \cdot(1 / 2-1-1-1)$ & $3 \cdot(1 / 2-1-1)$ \\
\hline
\end{tabular}

${ }^{37}$ Calvisius, Exercitationes, 11-14. 
Table 3 (continued)

\begin{tabular}{|l|c|c|}
\hline Lydian & $4 \cdot(1-1-1-1 / 2)$ & $1 .(1-1-1 / 2)$ \\
\hline Mixolydian & $1 .(1-1-1 / 2-1)$ & $2 .(1-1 / 2-1)$ \\
\hline Aeolian & $2 \cdot(1-1 / 2-1-1)$ & $3 .(1 / 2-1-1)$ \\
\hline
\end{tabular}

In addition, Calvisius emphasizes that these combinations alone are rationally possible: other combinations may be made, but they do not produce modes. ${ }^{38}$ Besides this general statement, Exercitationes do not give a more detailed explanation of the reasons for excluding the remaining combinations.

Calvisius also adopts Zarlino's order of the modes, justifying it precisely by the first (and, it would seem, the most important) of Zarlino's reasons for renumbering the system: if the Ionian mode with the final tone $\mathrm{c}$ is placed first, the sequence of the modes will follow their natural order. If the ratio of the octave $(2: 1)$ is divided according to its harmonic mean, one obtains exactly the same sequence of tones and semitones, that is characteristic of the first species of octave $(\mathrm{c}-\mathrm{c})$, within which the Ionian mode is located. ${ }^{39}$

In the Exercitationes the initial definitions are followed by a detailed presentation of individual modes ${ }^{40}$ schematically summarized in the table below. As is evident, Calvisius adopted Zarlino's order of the modes, but also took over their ancient names from Glarean's system.

Table 4

\begin{tabular}{|l|l|l|l|l|l|l|}
\hline No. & Name & A/P & F & A & AT & S \\
\hline 1 & Ionian & A & c & c-c & f-f & first species of fifth, first species of fourth \\
& Hypoionian & P & & g-g & c-c & \\
\hline 2 & Dorian & A & d & d-d & g-g & second species of fifth, second species of \\
& Hypodorian & P & & a-a & d-d & fourth \\
\hline 3 & $\begin{array}{l}\text { Phrygian } \\
\text { Hypophrygian }\end{array}$ & A & P & e - e & a-a & third species of fifth, third species of fourth \\
& b-b & e-e & \\
\hline 4 & Lydian & A & f & f-f & b-b & fourth species of fifth, first species of fourth \\
& Hypolydian & P & & c-c & f-f & \\
\hline 5 & Mixolydian & A & g & $\begin{array}{l}\text { g-g } \\
\text { d-d }\end{array}$ & $\begin{array}{l}\text { c-c } \\
\text { g-g }\end{array}$ & first species of fifth, second species of fourth \\
& Hypomixolydian & P & & d-d & g- & A fourth \\
\hline 6 & Aeolian & A & a & a-a & d-d & second species of fifth, third species of foun \\
& Hypoaeolian & P & & e-e & a-a & \\
\hline
\end{tabular}

$\mathrm{A} / \mathrm{P}=$ authentic or plagal mode

$\mathrm{F}=$ finalis

$\mathrm{A}=$ ambitus

$\mathrm{AT}=$ ambitus of the transposed mode (with the $\mathrm{b}$ flat)

$\mathrm{S}=$ structure of individual modes

Praetorius deals with the modes primarily in the second part of the first book of his Syntagma musicum, where the ancient modes are discussed in some chapters, and

\footnotetext{
38 Ibid., 12.

39 Ibid., 5, 8 .

${ }^{40}$ Ibid., 14-33.
} 
in chapter 6 of the second part of the third book, where the system of modern modes is presented. As in Zarlino's Istitutioni, Praetorius' treatment of the ancient modes is of little importance for understanding the modern ones; therefore, our focus should primarily rest on the latter. However, by comparison with the Istitutioni, the discussion of the modes in the Syntagma musicum is quite brief, and the system is presented only schematically. In the first section, the compasses of individual modes and their transpositions are given, accompanied by their names, numbering, finals and recitation tones (i.e., a note on which psalms were recited). The second section displays the whole compass of separate pairs of authentic and plagal modes as they apply to singing voices, while the presentation of the modes in the third section is intended "for the organist who is used to German tablature and who is perhaps unable to follow the notes properly". ${ }^{41}$

The reason for the brevity of his discussion is explained by Praetorius:

Indeed, in the fourth volume, God willing, I wish to offer the musical reader the opportunity of learning something concerning these matters and the many famous men [writing] in Italian and the Latin language, among whom is also Seth Calvisius, who have related most cogently the doctrine of the modes and why they should begin from the pitch ' $\mathrm{C}$ '. ${ }^{42}$

Clearly, Praetorius was planning to discuss the modes more fully in the (never published) fourth volume of Syntagma musicum. He was obviously familiar with the Latin writings of Seth Calvisius, who is explicitly referenced in the above passage, and from the introduction to the third book, we can also learn of the "many famous men [writing] in Italian". On this subject Praetorius writes:

Since we are all by nature obliged and bound to serve the common Fatherland, the author will shortly publish, God willing, his fourth volume of Syntagma musicum or

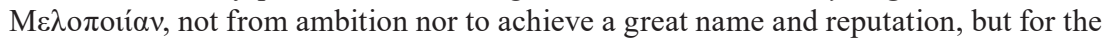
good of the German nation and the benefit of all music lovers. It will be compiled from the marvellous writings of Gioseffo Zarlino, Giovanni Maria Artusi, Pietro Ponzio, M. Orazio Tigrini, and other excellent authors. ${ }^{43}$

Regardless of whether Praetorius became acquainted with the work of these authorities directly or indirectly (via the writings of Calvisius, for example), it is evident that he was familiar with the ideas of the named Italian authors, among whom Zarlino is unquestionably the most prominent. In his Syntagma musicum Praetorius took over several of Zarlino's views, although in doing so he was not entirely consistent. Even if, according to the first of the above quoted passages, it would appear that he agreed with Zarlino's renumbering of the modes, both Glarean's and Zarlino's sequences are schematically presented in Praetorius' own system: the first is described as "common" (vulgatam opinionem), and

\footnotetext{
${ }^{41}$ Praetorius, Syntagma musicum III (2004), 65.

${ }^{42}$ Ibid., 54.

${ }^{43}$ Ibid., 9.
} 
the second as "Italian" (italorum opinionem) ${ }^{44}$ Praetorius' system for the modes ${ }^{45}$ is summarized in the following table.

Table 5

\begin{tabular}{|c|c|c|c|c|c|c|c|}
\hline No. G & No. Z & Name & $\mathbf{A} / \mathbf{P}$ & $\mathbf{F}$ & AS & AST & RT \\
\hline 1 & 3 & Dorian & A & $\mathrm{d}$ & $\mathrm{d}-g-\mathrm{d}$ & $\mathrm{g}-d-\mathrm{g}$ & $\mathrm{a}$ \\
\hline 2 & 4 & Hypodorian & $\mathrm{P}$ & $\mathrm{d}$ & $\mathrm{a}-d-\mathrm{a}$ & $d-g-d$ & $\mathrm{f}$ \\
\hline 3 & 5 & Phrygian & A & $\mathrm{e}$ & $\mathrm{e}-h-\mathrm{e}$ & $\mathrm{a}-e-\mathrm{a}$ & $\mathrm{c}$ \\
\hline 4 & 6 & Hypophrygian & $\mathrm{P}$ & $\mathrm{e}$ & $\mathrm{h}-e-\mathrm{h}$ & $\mathrm{e}-a-\mathrm{e}$ & $\mathrm{e}^{*}$ \\
\hline 5 & 7 & Lydian & A & $\mathrm{f}$ & $\mathrm{f}-c-\mathrm{f}$ & $\mathrm{b}-f-\mathrm{b}$ & $\mathrm{c}$ \\
\hline 6 & 8 & Hypolydian & $\mathrm{P}$ & $\mathrm{f}$ & $\mathrm{c}-f-\mathrm{c}$ & $\mathrm{f}-b-\mathrm{f}$ & $\mathrm{a}$ \\
\hline 7 & 9 & Mixolydian & A & $\mathrm{g}$ & $\mathrm{g}-d-\mathrm{g}$ & $\mathrm{c}-\mathrm{g}-\mathrm{c}$ & $\mathrm{d}$ \\
\hline 8 & 10 & Hypomixolydian & $\mathrm{P}$ & $\mathrm{g}$ & $\mathrm{d}-\mathrm{g}-\mathrm{d}$ & $\mathrm{g}-c-\mathrm{g}$ & $\mathrm{c}$ \\
\hline 9 & 11 & Aeolian & A & $\mathrm{a}$ & $\mathrm{a}-e-\mathrm{a}$ & $\mathrm{d}-a-\mathrm{d}$ & $\mathrm{e}$ \\
\hline 10 & 12 & Hypoaeolian & $\mathrm{P}$ & $\mathrm{a}$ & $\mathrm{e}-a-\mathrm{e}$ & $\mathrm{a}-d-\mathrm{a}$ & $\mathrm{a}^{\dagger}$ \\
\hline 11 & 1 & Ionian & A & $\mathrm{c}$ & $\mathrm{c}-\mathrm{g}-\mathrm{c}$ & $\mathrm{f}-c-\mathrm{f}$ & $\mathrm{g}$ \\
\hline 12 & 2 & Hypoionian & $\mathrm{P}$ & $\mathrm{c}$ & $\mathrm{g}-c-\mathrm{g}$ & $\mathrm{c}-f-\mathrm{c}$ & $\mathrm{e}$ \\
\hline
\end{tabular}

No. $\mathrm{G}=$ numbering according to Glarean (= common view)

No. $\mathrm{Z}=$ numbering according to Zarlino (= Italian view)

$\mathrm{A} / \mathrm{P}=$ authentic or plagal mode

$\mathrm{F}=$ finalis

$\mathrm{AS}=$ ambitus and structure of individual modes

AST $=$ ambitus and structure of individual transposed modes ${ }^{46}$

$\mathrm{RT}=$ reciting tone

* Apparently, an error has occurred, since a should be written in place of e.

$\dagger$ Apparently, an error has occurred, since c should be written in place of a.

For Praetorius, who published the third book of Syntagma musicum about fifty years after Zarlino first presented his renumbering of the modes in Dimostrationi harmoniche (1571), the Italian's order was obviously still a kind of novelty: Praetorius did not adopt it entirely, still referring in addition to Glarean's numbering and even characterizing it as "common". The reasons for presenting dual numberings should perhaps be sought within the broader concept of the Syntagma musicum. On the one hand, we should take into consideration that the treatise is widely, encyclopaedically conceived, and Praetorius may have included both numberings because of his desire to present a variety of theoretical views, ideas and traditions. On the other hand, we should not ignore the fact that Praetorius' treatise Syntagma musicum is in the final analysis far more practically oriented

${ }^{44}$ Ibid., 55.

${ }^{45}$ Ibid., 54-66.

${ }^{46}$ Like Calvisius, Praetorius included also transpositions of individual modes in his schemes, whereby the original mode is called durus and regularis, and the transposed one (with b flat) mollis and transpositus. (Praetorius, Syntagma musicum (2004), 55). In his Istitutioni Zarlino also speaks about possible transpositions of modes; however, neither he nor Calvisius in Exercitationes musicae duae makes use of the terms durus and mollis. 
than Zarlino's Istitutioni, and, as such, could have been intended to a greater extent for practical musicians, instrumentalists and singers. If so, we could perhaps assume that Zarlino's idea of renumbering the modes and placing the mode with finalis $\mathrm{c}$ at their head was not yet widely known among musicians in the German lands, where Praetorius worked and where the Syntagma musicum was published. So, by presenting both numberings, Praetorius oriented the content of his treatise towards practical musicians, while at the same time making sure that the Italian system (Zarlino's, which he seems to have been in agreement) was presented in easily assimilable form.

Praetorius was another who did not follow Zarlino in naming the modes: rather, like Calvisius, he consistently retained this aspect of Glarean's system. Unlike in the case of Zarlino's renumbering of the modes, Praetorius - again, like Calvisius - does not say a word about Zarlino's thoughts regarding the names of the modes. Once again, this suggests the possibility that he was acquainted with Zarlino's theorems only at second or third hand.

Moreover, from their schematic presentation in the Syntagma musicum we learn nothing about the characteristics of individual modes as discussed in the Istitutioni. From chapter 9 of the second part of the third book, where transposition is the topic, we learn only about the behaviour of some modes (or, to be more precise, the compositions written in these modes) when they are moved up or down in the tonal space. Here Praetorius writes that "several modes, such as Mixolydian, Aeolian, and Hypoionian, generate a drab and languid sound [harmonia] because of the lower tessitura [sonos] when transposed down a fifth" ${ }^{47}$ In Praetorius' opinion, therefore, it is better to transpose the compositions written in these modes a fourth up rather than a fifth down. He then adds some other examples and guidance for transposing compositions written in particular modes. ${ }^{48}$

If, after this survey of the modal systems as they are discussed in Zarlino's Istitutioni harmoniche and Praetorius' Syntagma musicum, we try to answer the question posed at its start (to what extent and in what way Praetorius adopted Zarlino's discussion on the modes), the following conclusion may be drawn: Praetorius must have known Zarlino's ideas - either indirectly, through the writings of other contemporary German authors, or directly - and adopted them in his treatise, though not consistently or completely. As Praetorius' discussion on the modes is relatively short and limited, a more in-depth and analytical answer is rather difficult to give. In this light, it really is a great pity that the fourth book of the Syntagma musicum was never published.

\footnotetext{
47 Praetorius, Syntagma musicum III (2004), 93.
}

${ }^{48}$ Ibid., 94-95. 


\section{Bibliography}

Barker, Andrew. Greek Musical Writings II: Harmonic and Acoustic Theory. Cambridge: Cambridge University Press, 1989. https://doi.org/10.1017/CBO9780511585753.

Bélis, Annie. “Aristoxenus". In Grove Music Online. Accessed 25 March 2019. https:// doi.org/10.1093/gmo/9781561592630.article.01248.

Calvisius, Sethus. Exercitationes musicae duae. Leipzig: Schnell, Apel, 1600.

Dahlhaus, Carl. Studies on the Origin of Harmonic Tonality. Translated by Robert O. Gjerdingen. Princeton: Princeton University Press, 1990. http://doi.org/10.1515/9781400861316. Glarean, Heinrich. Dodecachordon I. Translated by Clement A. Miller. [Dallas, TX]: American Institute of Musicology, 1965.

Judd, Christle Collins. "Renaissance modal theory: theoretical, compositional, and editorial perspectives." In The Cambridge History of Western Music Theory, edited by Thomas Christensen, 364-406. Cambridge: Cambridge University Press, 2002.

Lester, Joel. Between Modes and Keys: German Theory 1592-1802. Stuyvesant: Pendragon Press, 1989.

Palisca, Claude V. Humanism in Italian Renaissance Musical Thought. New Haven: Yale University Press, 1985.

_. Music and Ideas in the Sixteenth and Seventeenth Centuries. Edited by Thomas J. Mathiesen. Studies in the History of Music Theory and Literature. Chicago: University of Illinois Press, 2006. http://doi.org/10.5406/j.ctt1xcmq8.

Plato. The Republic. Translated by Tom Griffith. Edited by G. R. F. Ferrari. Cambridge: Cambridge University Press, 2003.

Powers, Harold S. et al. "Mode. III. Modal theories and polyphonic music". In Grove Music Online. Accessed 21 September 2019. https://doi-org.nukweb.nuk.uni-lj.si/10.1093/ gmo/9781561592630.article.43718.

Praetorius, Michael. Syntagma musicum I: Musicae artis analecta. Wittenberg: J. Richter, 1614/15. Facsimile edition, edited by Wilibald Gurlitt. Documenta musicologica 1, Druckschriften-Faksimiles 21. Kassel: Bärenreiter, 1959.

—. Syntagma musicum III: Termini musici. Wolfenbüttel: Elias Holwein, 1619. Facsimile edition, edited by Wilibald Gurlitt. Documenta musicologica 1, DruckschriftenFaksimiles 15. Kassel: Bärnreiter, 1958.

—. Syntagma musicum III. Translated and edited by Jeffery Kite-Powell. New York: Oxford University Press, 2004.

Wiering, Frans. The Language of the Modes: Studies in the History of Polyphonic Modality. New York: Routledge, 2001.

Zarlino, Gioseffo. L'istituzioni armoniche. Edited by Silvia Urbani. Treviso: Diastema, 2011.

- Le istitutioni harmoniche. Venice, 1558.

. De tutte l'opere del R. M Gioseffo Zarlino da Chioggia I: L'istitutioni harmoniche. Venice: Francesco de' Francesci Senese, 1589.

—. De tutte l'opere del R. M Gioseffo Zarlino da Chioggia II: Le dimostrationi harmoniche. Venice: Francesco de' Francesci Senese, 1589.

- On the Modes. Translated by Vered Cohen. New Haven: Yale University Press, 1983. 


\section{PRAETORIUS IN ZARLINO O MODUSIH}

Povzetek

Gioseffo Zarlino (ok. 1517-1590) je leta 1558 pripravil prvo izdajo svojega monumentalnega traktata o glasbi Le istitutioni harmoniche. Delo je še za časa njegovega življenja postalo široko poznano: o Zarlinovih teoretskih zamislih so razpravljali in jih prevzemali mnogi evropski teoretiki in skladatelji njegovega časa. Zdi se, da je bil med njimi tudi Michael Praetorius (1571-1621), ki je nameraval Zarlinove teoreme podrobno obravnavati v četrti knjigi Syntagme musicum, a ta žal nikdar ni izšla. Toda teoretska vprašanja so - čeprav večinoma le pregledno - obravnavana tudi v vseh treh objavljenih knjigah tega slovitega spisa o glasbi. Namen prispevka je ugotoviti, v kolikšni meri in na kakšen način je Praetorius prevzemal Zarlinovo razpravo o modusih.

Zarlino se je pri obravnavi modusov zgledoval po švicarskem teoretiku Heinrichu Glareanu (1488-1563), ki je v traktatu Dodecachordon (1547) predstavil sistem dvanajstih modusov, v katerega je ob srednjeveških osem modusov s finalisi na d, e, f in g umestil še štiri moduse s finalisi na c in a. Toda Zarlino Glareanovega sistema ni prevzel dosledno, temveč je vanj vpeljal nekatere spremembe, s katerimi ga je v prvi vrsti poskušal prilagoditi vseobsegajočemu glasbenemu sistemu, kot si ga je zamislil v Istitutioni. V traktatu Dimostrationi harmoniche (1571) je tako (1) predstavil drugačen vrstni red modusov in (2) utemeljeval, zakaj sodobnih modusov ni smiselno poimenovati z antičnimi imeni (oboje je zatem prevzel tudi v drugi izdaji Istitutioni iz leta 1573).

Iz vsebine Syntagme musicum ni povsem jasno, ali je Praetorius, ki je bil z Zarlinovimi glasbenoteoretskimi zamislimi gotovo seznanjen, le-te spoznaval neposredno ali posredno, prek spisov nekaterih drugih nemških teoretikov časa, posebno prek traktatov Setha Calvisiusa (1556-1615). Calvisius je svoj sistem modusov podrobno predstavil v spisu Exercitationes musicae duae (1600), v katerem je očitno sledil Zarlinovim zamislim, a z manjšimi odstopanji (med drugim je ohranil antična imena iz Glareanovega sistema, ki jih Zarlino zavrača).

Praetorius o modusih razpravlja predvsem v drugem delu prve knjige Syntagma musicum, kjer v nekaterih poglavjih obravnava antične moduse, in v šestem poglavju drugega dela tretje knjige, kjer oriše sodobni sistem modusov. A razprava o sodobnih modusih je v Syntagmi musicum v primerjavi z Istitutioni razmeroma kratka in sistem je ob avtorjevem namenu, da se bo tovrstnim vprašanjem podrobneje posvetil v kasneje neizdani četrti knjigi, le shematsko podan. Kljub temu lahko iz njega razberemo, da je Zarlinovo preštevilčenje modusov za Praetoriusa, čigar tretji del Syntagme musicum je izšel približno 50 let po tem, ko je bila nova ureditev v Dimostrationi prvič predstavljena, še vedno nekakšna novost, ki je ne prevzema v celoti, temveč ob njej še vedno navaja tudi Glareanovo zaporedje, ki ga tudi označi za običajnega (vulgatam opinionem). Praetorius Zarlinu ni povsem sledil niti pri poimenovanju modusov, saj je v tem primeru (enako kakor Calvisius) dosledno prevzel Glareanov sistem.

Ne glede na tovrstne odmike moremo iz vsebine Praetoriusovega spisa razbrati, da je Zarlinove zamisli gotovo poznal (bodisi posredno, prek spisov drugih nemških avtorjev časa, bodisi neposredno) in jih v svojem traktatu tudi prevzemal. 